\title{
Religião débil da caridade: 0 cristianismo não religioso em debate
}

\author{
Feeble religion of charity: non-religious Christianity in debate
}

PAULO SÉRGIO LOPES GONÇALVES (iDa

\section{Resumo}

O nosso objetivo neste artigo é analisar o cristianismo não religioso como uma religião débil, centrada na caridade, comprometida com a solidariedade e com o sonho de que os povos vivam a fraternidade, a justiça e a paz. Justifica este objetivo, a formulação desse cristianismo feita pelo italiano Gianni Vattimo, em que predomina a concentração na caridade articulada com a kenosis do Verbo, para apresentar um cristianismo encarnado na história humana. Além disso, esse filósofo levou a sua tese para o debate, em momentos diversos, com Richard Rorty, René Girard e John Caputo, favorecendo que a sua proposta se torne ainda mais densa por possibilitar pensar o cristianismo como religião débil da caridade. Para atingir esse objetivo, apresentar-se-á o cristianismo não religioso vattiminiano, seguindo algumas obras do autor; expor-se-á o debate junto aos pensadores supracitados de modo a suscitar três questões inferidas do próprio debate, evitando construir uma discussão meramente historiográfica. No entanto, buscar-se-á a construção de uma análise histórica, filosófica e teológica para mostrar a debilidade do cristianismo ao se concentrar na caridade, no seu caráter emancipador e na força de promover a fraternidade, a solidariedade e a paz.

Palavras-chaves: Cristianismo não religioso. Religião. Pensamento débil. Sacrifício. Esperança.

\section{Abstract}

Our aim in this article is to analyze non-religious Christianity as a weak religion, centered on charity, committed to solidarity and the dream that peoples live fraternity, justice and peace. This objective justifies the formulation of this Christianity by the Italian Gianni Vattimo, in which the concentration on charity articulated with the

\footnotetext{
a Pontifícia Universidade Católica de Campinas (PUC-Campinas), Campinas, SP, Brasil. Doutor em Teologia, e-mail: paselogo@puc-campinas.edu.br
} 
kenosis of the Word predominates, to present an Incarnate Christianity in human history. Moreover, this philosopher took his thesis to the debate, at various times, with Richard Rorty, René Girard and John Caputo, favoring that his proposal becomes even denser by enabling christianity to be thought of as a weak religion of charity. To achieve this goal, vattiminian non-religious Christianity will be presented, following some works of the author, the debate will be presented to the aforementioned thinkers in order to raise three questions inferred from the debate itself, avoiding building a purely historiographical discussion. But we will seek the construction of a historical, philosophical and theological analysis to show the weakness of Christianity by focusing on charity, its emancipatory character and the strength of promoting fraternity, solidarity and peace.

Keywords: non-religious Christianity. Religion. Weak thinking. Sacrifice. Hope.

\section{Status Quaestionis}

A formulação teórica do cristianismo não religioso realizada por Gianni Vattimo tem despertado interesse em pesquisadores tanto em decifrar quanto em debater o seu significado e o consequente impacto na contemporaneidade histórica e cultural (PAIVA, 2015). Justificam esse debate dois fatores fundamentais: a biografia do filósofo italiano, especialmente a sua obra intelectual, e as reações de filósofos que, também a modo próprio, se colocam a pensar o cristianismo na contemporaneidade.

Gianni Vattimo nasceu em 1936, tendo sido educado como cristão católico, inserido na Igreja católica, participando de atividades juvenis relacionadas à Ação Católica e sendo leitor assíduo de Jacques Maritain, principalmente de sua obra Humanisme Intégral (1936). É dessa vivência de um cristianismo inserido no mundo, preocupado preponderantemente com a dimensão social do Evangelho, que Vattimo se motiva a ingressar na Universidade de Turim para cursar Filosofia e, por conseguinte, a assumir o caminho de estudar e meditar filosoficamente as obras de Friedrich Nietzsche e Martin Heidegger - que são pensadores que representam uma virada filosófica sobre a questão do ser — e seus impactos históricos, antropológicos, religiosos e culturais (VATTIMO, 1998, p. 17-28).

Ao buscar conhecer esses pensadores alemães, Vattimo teve o amparo do filósofo italiano Luigi Pareyson, discípulo de Hans Georg Gadamer, que, por sua vez, foi uma de suas fontes para a tese de doutorado e também seu 
orientador quando por ocasião de seus estudos na Alemanha. Desse modo, Vattimo assumiu o caminho de uma hermenêutica niilista (FORTES DE SALES, 2015, p. 1590-1594) que conjuga a sentença nietzschiana da "morte de Deus" e o projeto heideggeriano de "superação da metafísica", passando a pensar a pós-modernidade (VATTIMO, 2006, p. 27-36), cuja categoria havia sido forjada por François Lyortard (1979).

Ao pensar a pós-modernidade (VATTIMO, 2002), principalmente como paradoxo de continuidade e descontinuidade da modernidade, Vattimo elabora a categoria "pensamento débil" - "pensiero debole" —, pela qual exprime o estado de espírito cultural e filosófico da sociedade contemporânea, trazendo à tona a condição de um pensamento que não mais se apresenta mediante as metanarrativas e fundamentação metafísica, mas pelas pequenas narrativas - tais como fábulas e contos - e por um espírito niilista-hermenêutico de reconfiguração de conceitos e hábitos vivenciais (VATTIMO, 2006, p. 106-109).

Ao unir a sua tradição religiosa e a categoria "pensamento débil", Vattimo passa a pensar filosoficamente o cristianismo - originariamente no seminário de Capri (DERRIDA; VATTIMO, 1994) e em seguida em suas obras Credere di credere (1998) e Depois da cristandade (2004) - partindo de sua matriz católica, de sua institucionalidade dogmática e moral, atendo-se à sua incidência na cultura ocidental e principalmente na mensagem do Evangelho referente à encarnação do Verbo e à caridade. É aqui que o autor se debruça sobre o modo como o cristianismo ateve-se à kenosis do Verbo para também se inserir no mundo, impulsionar a secularização e assumir a caridade como categoria central de sua própria missão. Assim sendo, Vattimo critica o cristianismo institucionalizado que se fundamenta em uma metafísica que absolutiza seus conceitos, tanto em seus dogmas, quanto em suas prescrições morais, fechando as portas à liberdade e ao diálogo pelo qual se expressa a verdade cristã. Por isso, o autor elabora a proposta de um cristianismo não religioso, denotativo de um nilismo hermenêutico centrado na kenosis do Verbo e na prática da caridade que se efetiva na sua relação com o mundo (VATTIMO, 2004, p. 7-16).

Esse cristianismo não religioso é o foco do debate de Vattimo com Richard Rorty, René Girard e Johnn Caputo. O diálogo com Rorty foi 
organizado por Santiago Zabala (2005) e concentrou-se em tomar a religião como assunto para se pensar os efeitos do pensamento débil presentes na hermenêutica niilista vattiminiana e no pragmatismo rortyano, caracterizando o "futuro da religião" como pós-religioso, em que paira uma "religião" sem ateísmo e sem teísmo. O debate com Girard foi organizado por Pierpaolo Antonello, tendo como núcleo fundamental a proposta de Vattimo concebida a partir da relação entre cristianismo e modernidade, visando compreender o sentido de ser cristão na era contemporânea (ANTONELLO, 2010). O debate entre Vattimo e Caputo foi organizado por Jeffrey W. Robbins (2010) e teve como ponto principal o pensamento débil e sua incidência na religião cristã, na política, na cultura e na própria teologia.

Esses debates trouxeram a Vattimo elementos importantes na constituição de sua obra Essere e dintorni (2017), na qual o autor analisou diversos assuntos filosóficos com incidência social, política, cultural, linguística, tendo na religião um elemento decisivo para pensar essas instâncias. Desse modo, o cristianismo não religioso alarga-se como uma proposta que, para além de uma alternativa para o cristianismo institucionalizado imbuído de dogmas e prescrições morais absolutizadas, é um cristianismo que aponta para o caráter caridoso, libertário e comunitário da religião.

Diante do exposto, objetiva-se neste artigo analisar o cristianismo não religioso como uma religião débil, centrada na caridade, comprometida com a solidariedade e com o alargamento de horizontes para que os povos vivam a fraternidade, a justiça e a paz. Para atingir este objetivo, apresentar-se-á o cristianismo não religioso vattiminiano, seguindo as obras mencionadas acima, expor-se-á o debate junto aos pensadores citados anteriormente de modo a suscitar três questões inferidas do próprio debate, evitando construir uma discussão meramente historiográfica. Buscar-se-á a construção de uma análise histórica, filosófica e teológica para mostrar a debilidade do cristianismo ao se concentrar na caridade, no seu caráter emancipador e na força de promover a fraternidade, a solidariedade e a paz. 


\section{0 cristianismo não religioso em afirmação}

A compreensão do cristianismo não religioso de Gianni Vattimo se vincula à sua compreensão de pensamento débil (ROTTERDAN; SENRA, 2015), como uma perspectiva para pensar o significado da pós-modernidade, caracterizada por François Loyotard como a era em que se alcança o fim das metanarrativas, fazendo aparecer as pequenas narrativas e visualizando uma sociedade transparente e flexível em seus costumes e imbuída de um processo de comunicação virtual (VATTIMO, 1992).

A categoria pensiero debole foi elaborada por Vattimo em conjunto com Pier Aldo Rovatti para apontar desde a leitura da sentença nietzschiana da "morte de Deus" até a afirmação heideggeriana acerca do esquecimento do ser por parte da metafísica. Trata-se de compreender que o Deus que morreu em Nietzsche é a metafísica a ser superada em Heidegger, concebida como a teoria denominada de ontoteologia, que absolutiza o ente, principalmente o ente supremo, e que se apresenta também no objetivismo da ciência moderna, que se pretende messiânica e capaz de resolver todos os problemas da humanidade. É essa metafísica que torna absoluto o seu conjunto de conceitos acerca de mundo, de homem e de Deus, que há de ser superada mediante o niilismo compreendido como destino, que possibilita descontruir esse substrato metafísico para abrir espaço ao pensamento hermenêutico do ser. Emerge, então, o pensamento débil, denotativo do enfraquecimento do ser, articulado à "meia luz", manifestado como recordação, rememorativo na estética, capaz de realçar a historicidade da existência humana e produzir uma verdade proveniente da "fusão de horizontes" e do diálogo entre os sujeitos que sem encontram no mundo (VATTIMO; ROVATTI, 1983).

Ao desenvolver o pensamento débil, Vattimo o aplica à análise da religião na pós-modernidade, visualizando-a como "vestígio do vestígio" (VATTIMO, 1994). Nessa análise, o ponto de partida é que a sentença nietzschiana acerca da "morte de Deus" trouxe à tona um conceito de secularização como oposição ao que é religioso e a possibilidade de extinção da religião e da questão de Deus na existência humana, realçando um ateísmo de negação e substituição da religião por parte da ciência e de Deus 
por parte do antropocentrismo e do naturalismo (MORRA, 1992, p. 31-52). A própria apologética teológica católica ateve-se a combater o ateísmo, o naturalismo e o racionalismo científico para afirmar a fé e a revelação como um conjunto de verdades imutáveis (GONÇALVES; SOUZA, 2013, p. 51-63).

Esse vislumbre acerca do fim da religião e da questão de Deus não aconteceu, e o que se testemunha em termos pós-modernos é que o retorno da religião parecia já pertencer a um passado impossível de ser retomado. Reativou-se um vestígio adormecido, reabriu-se uma ferida, reapareceu o que havia sido removido e o que parecia ser Überwindung manifestou-se como Verwindung, uma convalescença que há de enfrentar o vestígio de sua doença (VATTIMO, 1994, p. 91-94). Essa convalescença é explicada na própria sentença nietzschiana da "morte de Deus", em que, ao declarar que Deus estava morto e que os homens o haviam assassinado, o "homem louco" afirmava que os coveiros ainda não sabiam dessa morte, pois ainda era demasiado cedo para enterrar Deus (GONÇALVES, 2014, p. 238-245).

Se o retorno da religião denota convalescença, então a religião que retorna está relacionada à crise da metafísica intrínseca à sentença nietzschiana e ao projeto heideggeriano supracitados. Trata-se então de compreender que há uma crise do fundamento metafísico apresentada na concepção de Deus e também nas certezas da ciência moderna, havendo necessidade de uma nova configuração a respeito da religião. Nesse sentido, o próprio Heidegger fazia a passagem do fundamento - Grund - para o sem fundamento - Abgrund - ou propriamente o abismo, ou ainda mais fundo por estar sem fundo (HEIDEGGER, 1976, p. 125-176). Adere-se então a um processo hermenêutico que recupera a historicidade e a humanidade dos acontecimentos religiosos, para que se infira o divinum ou o sacro impregnado na própria experiência da religião que retorna (VATTIMO, 1998, p. 7-17).

O retorno da religião ocorre em uma época marcada por crise ecológica, por manipulações genéticas muitas vezes isentas de eticidade, pelo retorno culturalista como forma de recusa da modernização, pela "dissolução generalizada das certezas racionalistas das quais o sujeito moderno se alimentou, exatamente aquele sujeito para o qual o sentimento de culpa e a 'inexplicabilidade' do mal são elementos tão centrais e decisivos” 
(VATTIMO, 1994, p. 100) e pela crise de sentido da existência do humanum. Essa religião que retorna retoma o mito não como configuração enganosa e irreal, mas como expressão linguística da realidade experimentada pelo homem, que propicia a recuperação da arché de seu sentido religioso e a reconfiguração hermenêutica da relação entre o humanum e o divinum, pondo-se a dar novas explicações sobre o sacro emergente na pósmodernidade (VATTIMO, 1994, p. 98-102; TERRIN, 2004, p. 74-87).

A religião que retorna em clima pós-moderno possui paradoxalmente as marcas da pluralidade cultural e religiosa e a hegemonia da tradição judaico-cristã, que por suas próprias características insere-se como religião no mundo. A partir da inserção, os valores religiosos dessa tradição são assumidos de modo reconfigurado no mundo, resultando desse processo o conceito de secularização. Desse modo, esse conceito não é necessariamente sinônimo de contraposição aos substratos religiosos, mas a outra face da própria religião à medida que valores religiosos circulam e penetram o mundo, vindo a fincar e prevalecer nas relações sociais e inter-humanas (VATTIMO, 1998, 29-35).

Essa compreensão niilista hermenêutica da secularização na cultura ocidental remete Vattimo a olhar para um elemento pertinente e relevante no cristianismo: a afirmação da kenosis do Verbo. Esse evento kenótico de revelação é marcado pelo amor, cuja efetividade encontra-se narrada nos Evangelhos denotativos da prática caridosa de Jesus junto aos fracos deste mundo, acolhendo-os e libertando-os dos males que os assolam em forma de injustiças, doenças e outras situações de sofrimento. Essas ações são denotativas da caridade, o que propiciou à tradição da fé cristã afirmar que Deus caritas est, justificando a recusa de um Deus que seja um ente supremo, estático, perfeito, onipotente e onisciente e que se impõe à realidade humana mediante dogmas, prescrições morais e punições. A encarnação remete a um Deus que gratuita e amorosamente se revela assumindo a carne humana e experimentando a historicidade dos seres humanos, em suas situações dramáticas de existência. Desse modo, remete ainda a não mais dividir a história em profana e sagrada ou colocar a história da salvação em paralelo com a história dos homens, mas a dar caráter unitário à história e apresentar efetivamente a salvação na própria história. Por isso, a salvação 
não é um dado metafísico objetivista, absolutizado, e que se impõe de cima para baixo em termos conceituais, mas uma realidade que requer compreensão e interpretação dos acontecimentos históricos denotativos da efetividade da caridade (VATTIMO, 2004, p. 75-88).

Da centralidade da caridade no cristianismo emerge a crítica ao cristianismo institucionalizado - e mais especificamente à Igreja católica -, que se concentra em realizar afirmações dogmáticas, morais e disciplinares com conotação metafísica autoritária e sem ater-se à hermenêutica. A crítica de Vattimo é inicialmente ao papado de João Paulo II, que moralmente se contrapôs de forma rígida em relação a temas como aborto, eutanásia, homossexualidade e manteve-se forte em dogmas cristãos, especialmente os da assunção e da imaculada conceição de Maria, do pecado original e da doutrina do novíssimos, principalmente a questão do inferno e do purgatório. Essa rigidez se impõe metafisicamente de modo a distanciar-se da situação hermenêutica desses temas e a rejeitar novas possibilidades de compreensão e interpretação. Desse modo, o cristianismo institucional permanece no âmbito da violência da metafísica à medida que concebe esses temas com uma visão unilateral e absoluta.

Algo similar é possível afirmar acerca da ciência moderna, que se pretende messiânica, capaz de resolver todos os problemas humanos, absolutizando as expressões das verdades que nela são apresentadas (VATTIMO, 2004, p. 55-72). À medida que a ciência se impõe como verdade em suas expressões, a sua formulação se torna metafísica e se fecha às possibilidades hermenêuticas plausíveis de apresentação da verdade emergente da investigação científica. A superação dessa metafísica requer a evocação da hermenêutica gadameriana (GADAMER, 2003) acerca da "fusão de horizontes" e do consequente diálogo que coloca os sujeitos envolvidos em um processo de comunicação, marcado pela emergência da alteridade que propicia compreender o outro em sua condição de outro e pela liberdade dos sujeitos envolvidos nesse processo (VATTIMO, 2016, p. 8-17).

A evocação da liberdade e da alteridade remete à própria caridade. A isenção da caridade na práxis cristã impossibilita a liberdade, para a qual Cristo libertou os seres humanos, e impede que a alteridade - da qual emergem a sensibilidade pelo sujeito diferente, o respeito e o acolhimento ao 
outro tal como se manifesta - se desenvolva na convivência social, cultural e religiosa. Assim sendo, a caridade se identifica com a verdade cristã, que não é concebida como correspondência às proposições, mas como proveniência da experiência da liberdade e da alteridade presente nas relações marcadas pela reciprocidade, corresponsabilidade e solidariedade, visando que $\mathrm{o}$ homem viva o próprio novum do Evangelho (VATTIMO, 2016, p. 58-66).

Essa vivência do Evangelho na contemporaneidade de cada época histórica, Vattimo já visualizava na análise heideggeriana das cartas paulinas, no curso de Fenomenologia da vida religiosa, ministrado em 1920-1921 (HEIDEGGER, 1995), ao trazer à tona a categoria faktische Lebenserfahrung, referindo-se ao "como" - "Wie" — viver a fé cristã de modo eficaz. A vida fática é, então, o espaço para a vivência da fé cristã e da experiência religiosa dela decorrente, em que se busca levar a cabo historicamente os valores intrínsecos à própria fé cristã. Nisso reside a própria existência autêntica para quem tem fé: encontrar no "como" — "Wie" — um modus vivendi à luz da fé. Esse modus é histórico, determinado por contornos culturais e vitais dentro dos quais a pessoa cristã está imersa e também marcado pelo contorno escatológico - uma espécie de motor da própria práxis cristã —, tão próprio do cristianismo. A experiência religiosa como experiência fática de vida é decorrente da escuta do ser que advém para dar-se ao homem, encontrando na linguagem a sua morada (HEIDEGGER, 1976, p. 313-374). Por isso, a linguagem religiosa há de conter a caridade desenvolvida na relação entre os seres humanos, marcada pela acolhida às diferenças culturais, religiosas e de gênero e pelo empenho à justiça social. Para isso, o ponto crucial do cristianismo não religioso é que se deva recordar a referência da teologia trinitária, em que se acentua a comunhão das pessoas divinas e sua revelação pela mediação do Verbo que se fez carne - história e humanização - e que doou o Espírito para que pairasse em seus discípulos, visando à efetividade da caridade na história (VATTIMO, 2004, p. 151-167).

O modo de viver a fé cristã - "Wie' — na história conduziu Vattimo a pensar o cristianismo na situação hermenêutica da Europa (VATTIMO, 2017, p. 253-266), continente em que vive, visando superar o cristianismo eurocêntrico que foi crucial no processo de colonização de povos da África e da América Latina. Não obstante a admissão do pluralismo cultural e 
religioso, há a hegemonia do cristianismo na formação da cultura ocidental, denotativa também de um processo de secularização da religião, resultando no fornecimento de valores religiosos à cultura e à política, hegemonicamente cristã. Por isso, os conflitos culturais e religiosos procedem da relação do cristianismo com as outras religiões no próprio processo de constituição da denominada cultura ocidental. Resulta, então, que o conceito de laicidade, do qual procede a ampliação do espaço para a manifestação da diversidade religiosa, é compatível com a relação do cristianismo com o mundo ou propriamente com a emergência da secularização. Por isso, o cristianismo possui vocação à laicidade, no sentido de assumir a responsabilidade pelo destino da modernidade, assumindo o universalismo de forma pós-moderna, mediante a hospitalidade - categoria tomada de Jacques Derrida - do outro, compreendido em sua identidade e diferença tão próprias e que são tão presentes atualmente na história. Além da compreensão, a hospitalidade requer dar espaço para que os hóspedes falem e sejam escutados por quem os hospeda e os acolham em sua outridade, propiciando liberdade e criação de espaços para o "diálogo entre religiões, visões de mundo, orientações ideais e culturas diversas" (VATTIMO, 2004, p. 126). Ao se constituir como religião da hospitalidade, o cristianismo se concentra na caridade para superar os dogmatismos, os moralismos e as normatividades disciplinares que são autoritários e nada evocam de liberdade, de respeito, de abertura ao diálogo, de comunhão nas diferenças e de construção da paz social e histórica (VATTIMO, 2004, p. 117-128).

Conforme o exposto, a tese vattimiana referente ao cristianismo não religioso acentua duas afirmações decorrentes da centralidade da caridade articulada com a kenosis do Verbo. A primeira é de que a verdade cristã não se situa em formulações de correspondências, que se fecham em suas prescrições, mas à própria hermenêutica referente à compreensão do ser cristão em consonância com a época histórica em que esse mesmo ser se situa. Trata-se de compreender que "o ser não se dá senão em uma abertura epocal instituída pelo ser-aí" (VATTIMO, 2017, p. 289), o que implica compreender as novas configurações da história em sua contemporaneidade, requerendo uma ontologia hermenêutica da atualidade que produza seres humanos livres, solidários, fraternos, capazes de construir ordens políticas 
que tenham marcas da democracia comunista (VATTIMO, 2017, p. 277-290). A segunda é que a religião cristã, por ser hegemonicamente a responsável pelo processo de secularização, possui potência de transformação social, inclusive no âmbito global, propiciando a efetividade da justiça em todas as suas dimensões. Essa potência emancipatória do cristianismo é possível à medida que os pobres se tornam os interlocutores principais da religião, para que a incisão na política os tenha também como protagonistas e destinatários da justiça.

Inspirando-se no Papa Francisco, considerado o maior líder atual que possui carisma para potencializar um processo de transformação global, Vattimo afirma ser a religião luz, força, memória — do sofrimento — para os pobres superarem uma sociedade fundamentada na organização total Verwaltung - mediante a promoção da libertação e de uma "revolução permanente", que tem na laicidade um espaço para a implementação de uma ética cristã do amor, capaz de desvelar as situações de injustiça e apontar um novo caminho para a humanidade (VATTIMO, 2017, p. 267-276).

\section{O cristianismo não religioso em debate: uma religião débil da caridade}

A proposta vattimiana acerca do cristianismo não religioso se concentra na caridade concebida desde a kenosis do Verbo, tem na secularização a sua outra face e objetiva superar a verdade como correspondência às proposições e concebê-la mediante um processo hermenêutico de diálogo e "fusão de horizontes" de sujeitos envolvidos em tal processo. Trata-se de uma proposta que coloca o cristianismo no âmbito das relações inter-humanas, ultrapassando a instituição religiosa, em sua condição de organização que possui dogmas, prescrições morais, normas disciplinares e se mantém rígida em vários de seus temas propriamente religiosos e éticos. As expressões de verdade oriundas de um processo hermenêutico do diálogo denotam uma densa crítica à metafísica objetivista tanto no âmbito religioso quanto no científico.

Conforme o exposto, a proposta vattimiana é provocativa à medida que pode fazer com que o leitor pense em um cristianismo isento de 
institucionalidade, com uma concepção de verdade distinta de suas expressões e imbuída das marcas da flexibilidade e do nomadismo epistemológico por originar-se de uma hermenêutica niilista. Por ser provocativa, essa proposta nos põe a pensar e visualizar o debate em torno de três questões: em que medida a religião é necessária para a efetividade de um projeto político democrático? Como é possível o cristianismo se relacionar com outras religiões sem mostrar-se hegemônico e imperativo? Poderia a caridade efetivar-se em articulação com a debilidade dos acontecimentos, onde se situam os fracos deste mundo?

A primeira questão remete ao diálogo de Vattimo com o filósofo norteamericano Richard Rorty, responsável por desenvolver uma pragmática filosófica, situada proximamente à filosofia hermenêutica. Esse filósofo se autodenomina ateu ou propriamente antieclesiástico e compreende que o cristianismo não religioso vattimiano é consequência do clima filosóficocultural de antiessencialismo, instaurado na contemporaneidade especialmente por Nietzsche, Heidegger — as esteiras de Vattimo -, Dewey e Wittgenstein - esteiras epistemológicas de Rorty -, em que se realça a historicidade dos eventos, a dissolução da dura oposição entre religião e ciência e a interconexão das esferas da cultura umas nas outras (RORTY, 2005, p. 33-36).

Richard Rorty reconhece que Vattimo é um filósofo teísta, que assume ou reassume a religião concentrando-se na encarnação do Verbo de Deus na história humana. A encarnação é um ato de Kenosis, em que Deus cede tudo aos seres humanos ou propriamente se autoesvazia, o que propicia a Vattimo afirmar que a secularização é a outra face da experiência religiosa, concentrada na caridade, concebida como o amor em movimento, que promove a amizade entre os seres humanos. Por isso, o cristianismo é uma religião da caridade efetivada na amizade presente nas relações intersubjetivas e na relação cooperativa entre os povos, cujas marcas são o diálogo, o respeito, a solidariedade e principalmente a liberdade. A religião cristã assim caracterizada é na visão rortyana um movimento rememorativo da kenosis divina presente em Jesus e que se realiza de forma privada, ainda que tenha elementos comunitários que impulsionam um novo humanismo, 
em que é possível respeitar a pluralidade cultural e religiosa e encontrar uma maneira fraterna de convivência humana (RORTY, 2005, p. 36-40).

A despeito do respeito e da proximidade de Rorty a Vattimo, o filósofo norte-americano entende que para a religião, quando é pensada a partir da caridade, os temas do teísmo e do ateísmo não são os mais importantes, mas é a própria prática da caridade em forma de solidariedade que produz esperança de um futuro melhor para a humanidade. Esse futuro pode ser a democracia, compreendida em sua condição de um modelo político de vigência da liberdade nas relações entre os seres humanos. Pode-se pensar também no comunismo, não aquele de cunho estatal e que se tornou totalitário, mas o que proporciona a efetividade da justiça em todas as suas dimensões, da convivência fraterna e respeitosa entre os membros de uma sociedade, da prática da solidariedade de modo a suprir as carências econômicas e sociais. Nessa humanidade, a lei única da sociedade será o amor - caridade - , concebido como única virtude capaz de proporcionar um sentimento de dependência tanto aos crentes quantos aos ateus: o de que há esperança de efetividade da justiça, da fraternidade e da paz (RORTY, 2005, p. 41-45).

A segunda questão nos remete ao diálogo realizado entre Gianni Vattimo e René Girard, em que ambos afirmam a fé cristã e a sua operação pela caridade. Nesse diálogo, Vattimo afirma sua dívida para com Girard no que se refere à teoria do sacrifício, em que o pensador francês distinguiu os sacrifícios mitológicos - sacrifícios trágicos de culpabilidade - dos sacrifícios bíblicos - sacrifícios trágicos de redenção e de salvação. Para o filósofo italiano, Girard completa o pensamento heideggeriano que para superar a metafísica explicitou a história da ontoteologia, mostrou que a metafísica havia se esquecido do ser e apresentou a existência autêntica desde o advento do ser ao homem mediante a linguagem, que habita o ser em sua época histórica. Desse modo, a perspectiva heideggeriana se identifica com a teoria girardiana no que se refere à revelação judaico-cristã, em que a história da salvação culmina em Cristo, sendo o seu sacrifício da cruz um sacrifício amoroso. Ora, se em Heidegger é possível visualizar o enfraquecimento do ser que advém ao homem na linguagem, que se abre para o aberto ou ao novum, em Girard a força de Deus se situa na fraqueza de 
Cristo presente na cruz, cujo sacrifício, a despeito de ser violento, é o elemento que põe fim à violência. Assim sendo, a essência da violência está desmascarada no sacrifício amoroso de Jesus na cruz, pois a violência está conectada com a essência do sagrado em função da kenosis de Cristo ser amorosa e incisiva na salvação dos seres humanos. A salvação não é uma questão de consciência que coloca o ser humano a escolher entre a violência e a caridade, mas é o anúncio de que a ação salvífica de Deus é realizada em um "processo histórico de educação, que é, ao mesmo tempo, uma revelação e uma progressiva redução da violência original do sagrado" (VATTIMO, 2010, p. 92). A salvação é então um processo em que Deus chama o homem a dessacralizar a violência e para dissolver a definitiva reivindicação da objetividade metafísica. Por isso, Vattimo é tão contundente em afirmar que a história da salvação é uma história da interpretação ou propriamente a hermenêutica que produz liberdade, fraternidade, justiça e paz (VATTIMO, 2010, p. 83-93).

René Girard elabora o seu pensamento articulando filosofia e antropología, debruçando-se na análise de mitos e ritos religiosos arcaicos, tendo em vista compreender o rumo que a humanidade realiza para si mesma. Assim sendo, ao analisar sacrifícios, desenvolveu a teoria do bode expiatório e o respectivo mecanismo vitimário, no qual se aponta a escolha de uma vítima para assumir a culpa de uma situação trágica, para satisfazer uma comunidade acusadora ou expiar erros ou pecados visando satisfazer uma comunidade culpada. Desse modo, sua teoria do bode expiatório pressupõe os dramas humanos e a busca pela causa de uma determinada situação e os seus respectivos culpados. Debruça sobre a relação entre a violência e o sagrado mediante a análise do sacrifício, sua respectiva crise, presente nos mitos e sua consolidação no universo bíblico, desenvolve o significado de desejo mimético como forma de levar a cabo a repetição dos sacrifícios e analisa como os ritos sacrificais mantêm-se em unidade a despeito de sua diversidade (GIRARD, 1990). A partir dessa relação entre a violência e o sagrado, aprofunda a teoria do bode expiatório, estabelecendo os estereótipos da perseguição, explicando o conceito de mito e, fazendo uso dele para explicitar a violência como realidade intrínseca à própria 
história dos seres humanos, penetra o universo bíblico para distinguir as suas configurações literárias da configuração do mito (GIRARD, 2004).

A obra girardiana mostra que, a despeito de Vattimo assumi-lo como uma de suas fontes, a sua teoria é diferente daquela do filósofo italiano. A primeira diferença é que Girard compreende que não há apenas interpretações, mas também fatos, especialmente quando se trata de analisar a concessão vitimaria do sagrado, pois o bode expiatório emerge da própria relação entre a violência e o sagrado. Em qualquer situação, o sacrifício - principalmente o de sangue - possui violência e crueldade; porém, é preciso diferenciar os sacrifícios arcaicos - presentes nos mitos do sacrifício de Cristo - presente no universo bíblico. Os primeiros são acusativos, buscam culpado(s) para determinada situação que atinge a coletividade e produzem o respectivo linchamento, como forma de compensar ou resolver a culpa. No sacrifício de Cristo, a vítima é culpada por um sistema mimético sacrifical, o que propicia pensar a morte de Jesus analisando o seu respectivo contexto histórico, a correlação de forças político-religiosas e o significado da morte em seu contexto vital (GIRARD, 2010, p. 95-103).

A segunda diferença consiste em que a análise girardiana ainda exige olhar também para aquilo que diz a Igreja em sua tradição: Jesus se sacrifica a si mesmo ou realiza o dom de si por amor, como forma de realizar a redenção e a salvação. Nesse sentido, o sacrifício de Cristo não é um mito, mas uma narrativa que afirma a perseguição vitimaria no próprio contexto, a violência coletiva à vítima e também a benfeitoria do próprio Cristo ao se doar para ser sacrificado. A própria entrega sacrificante não pode ser concebida sem a luz da ressurreição, que é o elemento que dá novo significado ao mecanismo vitimário - que denota a força dos perseguidores para encontrar o culpado, acusá-lo e condená-lo à pena máxima - inclusive criando nova configuração da própria cena. Reconfigura-se hermeneuticamente a força dos perseguidores trazendo à tona a eficácia da perseguição em função da potência da ressurreição que propicia a definitiva vitória da vida sobre a morte. Mesmo que a perseguição produza contágio aumentando o número de perseguidores, podendo inclusive ter atingido os próprios apóstolos de Jesus, a ressurreição é a superação da perseguição em sua totalidade, por se 
tratar de uma ação divina que ressuscita o crucificado. Essa ação divina denota que, a despeito de sua violência, a crucificação evidencia o amor de Jesus como vítima pascal, visando a redenção e salvação dos seres humanos. Destitui-se, então, o mecanismo vitimário de sua força poderosa e realça-se o amor presente no sacrifício de Cristo (GIRARD, 2010, p. 103-119). Tem-se então a revelação da violência intrínseca a todo e qualquer sacrifício, mas há a prevalência do amor, já presente na paixão e na morte, e estampado definitivamente na ressurreição de Jesus (GIRARD; VATTIMO, 2010, p. 43-46).

A terceira diferença mostra que a recepção crítica girardiana acerca do cristianismo não religioso de Vattimo apresenta a radicalidade do cristianismo: ser uma religião do sacrifício amoroso que promove a vida, ainda que a violência se apresente na história e seja intrínseca à própria existência dos povos. Nesse sentido, mesmo que o cristianismo protagonize o amor na história, não o faz sem a companhia do outro, presente nas religiões e nos demais segmentos sociais e culturais. Resulta, então, ser legítimo discursar sobre a laicidade da sociedade, que não implica rechaçar as religiões e tampouco declarar ateísmo para todas as pessoas de uma sociedade, mas aderir ao pluralismo, fermentar a convivência concentrada no amor que evoca respeito, corresponsabilidade, reciprocidade, liberdade e uma política capaz de promover o bem maior da humanidade (ANTONELLO, 2010, p. 5-22). Em outras palavras, a universalidade de Cristo presente em seu sacrifício amoroso possibilita pensar não apenas o protagonismo do cristianismo, mas das religiões e das instâncias que efetivamente vivem o amor em realidades concretas de unidade e de paz.

A terceira questão remete-nos ao diálogo entre Vattimo e John Caputo, também católico e italiano - um "italiano débil, um quase-italiano, um simulacro de italiano que não fala italiano, afastado duas gerações da ancestral cidade de Nápoles, e, sem dúvida, um ainda mais débil católico" (CAPUTO, 2010, p. 113). Esse pensador foi também leitor assíduo do neotomista Jacque Maritain em sua juventude pré-universitária, obtendo elementos para uma crítica da modernidade. Ao ingressar na universidade, imergiu na filosofia contemporânea, especialmente na ontologia hermenêutica de Heidegger, tendo encontrado no filósofo alemão um último grito da fenomenologia europeia para criticar a modernidade. Caputo 
concorda com a análise que Vattimo faz acerca do papado de João Paulo II, criticando os seus posicionamentos eclesiológicos e políticos, e ainda encontrou o seu caminho cristão para além do catolicismo convencional, mediante Nietzsche, Heidegger, Gadamer e principalmente Derrida, esteira esta que caracteriza a hermenêutica radical desenvolvida pelo pensador ítaloamericano (CAPUTO, 2010, p. 112-118).

Em sua hermenêutica radical, Caputo se concentra na debilidade do pensamento, utilizando-se do método de desconstrução derridiano e assumindo o desafio de pensar a religião no clima da pós-modernidade. Para isso, o autor compreende que o cristianismo não religioso vattimiano ainda carece de aprimoramento da própria debilidade do pensamento incisivo na teologia e na própria prática religiosa, que influi na sociedade e na cultura. Resulta, então, que a hermenêutica caputiana respeita o niilismo hermenêutico de Vattimo - no qual estão conjugadas a sentença nietzschiana da "morte de Deus" e o projeto heideggeriano de "superação da metafísica", e a compreensão da secularização como a outra face da religião, especialmente a cristã -, mas busca apresentar uma epistemologia da debilidade incisiva na concepção de religião, de Deus e de sua ação no mundo em que habita o homem.

O ponto de partida de Caputo é apresentar uma "teologia do acontecimento", fazendo a distinção entre acontecimento e nome. Afirma o acontecimento como algo que subjaz na ocorrência e não o que ocorre, dando-lhe sentido e dinamizando-o para não permanecer em única forma. Nesse sentido, o acontecimento é simultaneamente frágil e absoluto, abrigo e refúgio, possui caráter evocativo e convocatório e é imbuído de energia vibradora (CAPUTO, 2010, p. 75-83).

O ocorrido do acontecimento é o nome ou o substrato nominativo que serve para dar morada ao acontecimento. Por ser dinâmico, o acontecimento simultaneamente se vincula e se desvincula, configura e reconfigura, dá sentido e muda o sentido do próprio nome. Por isso, ao se nomear Deus, há um acontecimento que dá sentido a esse nome e um acontecimento religioso à medida que a religião é o contrato firmado entre esse mesmo acontecimento e os seres humanos. Ao abrigar um acontecimento religioso, o nome de Deus requer um pensamento radicado hermeneuticamente, que 
denota "chama eterna" e, por isso, evoca um mistério inacessível em sua totalidade - caso contrário deixaria de ser mistério - e acessível em seus "vestígios de fogo", em sua sacralidade que remete à dialética da distância e proximidade. Por estar contido de mistério, o acontecimento é promessa a ser realizada, irredutível e incondicional, que se realiza na condicionalidade temporal e espacial, na palavra discursiva e propositiva, e se alimenta da promessa que tornou possível a sua efetividade (CAPUTO, 2010, p. 83-92).

Ao se constituir de promessa, o acontecimento desperta o desejo do homem por Deus, considerado o abrigo do acontecimento. $O$ desejo é o desconhecido - o segredo absoluto - e encontra sua vivacidade no acontecimento, que, sendo dinâmico, possibilita que haja busca do homem por Deus - o buscado e desejado - na própria historicidade do acontecimento, na qual está situada a própria relação do homem com Deus. Ao considerar a pulsação do desejo por Deus na historicidade do homem, Caputo apresenta a debilidade de Deus, no sentido de seu nome poder ser concebido à medida que Ele acontece na própria história, marcada por tensões, dramas, potencialidades e outras realidades profundas da existência humana. Por isso, o acontecimento é dinâmico, nômade e provoca a hospitalidade dos sujeitos que nele estão envolvidos (CAPUTO, 2010, p. 93-96).

O acontecimento como desenvolvimento da chegada do nômade e realização da hospitalidade por parte de quem está na casa denota a debilidade de Deus, que encontra na religião cristã o seu ápice na cruz, que, por sua vez, possui consonância com a categoria Reino de Deus, herdada do judaísmo, imbuída de caráter apocalíptico e de esperança escatológica. Tanto a cruz quanto o Reino de Deus possuem uma lógica da debilidade, pois ambas explicitam o reverso da história, a loucura da presença de Deus na história a partir dos fracos e a manifestação da mansidão diante da violência, do perdão diante da vingança, da justiça defronte à injustiça e do amor na contraposição ao ódio (CAPUTO, 2012, p. 96-112).

Emerge dessa experiência uma teologia débil que reflete $\mathrm{O}$ acontecimento, concebendo a religião como oração, lágrimas e como acontecimento da interlocução entre Deus e os seres humanos desde o locus histórico do sofrimento humano, do espírito da hospitalidade — khora em 
linguagem derridiana - desenvolvida no deserto da própria história e que propicia a abertura das portas de casa para os outros, constituídos de culturas e religiosidades diferentes. Por isso, a hermenêutica radical, também chamada de espectral, elaborada por Caputo, acolhe o cristianismo não religioso, conjugando a caridade com a hospitalidade, propiciando uma religião cristã débil, constituída a partir da debilidade da história, destituída e despojada de poder, aberta ao incondicional, que caminha no deserto para acolher aqueles que estão em busca da promessa de realização efetiva do Reino de Deus (CAPUTO, 2012, p. 217-229).

Essas questões disputadas refletem que o cristianismo não religioso formulado por Vattimo é uma religião débil da caridade, incisiva socialmente, de espírito ecumênico e inter-religioso e situada nos loci historici dos fracos. Por isso, é um proposta pós-moderna denotativa do enfraquecimento do ser manifestado nas instituições - inclusive as religiosas -, nas concepções epistemológicas - das afirmações dogmáticas, das prescrições morais e das normas disciplinares -, no modo como as relações inter-humanas têm se desenvolvido, no reconhecimento das diversas formas de vulnerabilidade, na apropriação das singularidades culturais, religiosas e sociais e nas novas formas de comunicação do humanum, que propicia evocar o "quarto uomo" (MORRA, 1992, p. 11-29) com o ser humano propriamente pós-moderno.

A caracterização da proposta de Vattimo como uma religião débil da caridade é um incremento oriundo do debate supra-apresentado, que recupera o cristianismo como uma religião que, por mais que tenha as marcas da transcendência, jamais deixou de ser uma religião da imanência. E por mais que o cristianismo exija um modus vivendi da fé para cada pessoa, não deixou de ser uma religião comunitária, cuja fé se vive em communitas fidelium. Nesse sentido, pertence ao escopo do cristianismo apresentar o Evangelho como "evangelium vitae" (JOÃO PAULO II, 1995), produtor de "gaudium" (FRANCISCO, 2013) aos seres humanos, porque sua boa notícia é a salvação efetivada na prática da caridade. A realização da caridade ocorre no encontro entre as diferenças, cada qual com sua memoria vitae et passionis (METZ, 2007), na compaixão entre as pessoas, na colaboração mútua dos povos, na busca de uma política denotativa de liberdade e de preocupação com o bem comum. Efetiva-se ainda a caridade mediante a construção de relações inter- 
religiosas (GEFFRÉ, 2013), da convivência social entre pessoas religiosas e pessoas seculares (HABERMAS, 2003), evidenciando a laicidade como espaço para que o cristianismo se mostre como religião débil, que se situa a partir dos débeis da história, capaz de promover a caridade em consonância com a compaixão, com a solidariedade e com a esperança de um novo futuro do humanum et mundi (GONÇALVES, 2015).

\section{Considerações finais}

Ao final deste artigo, urge retomar os seus pontos fundamentais, marcados pelo objetivo de apresentar analiticamente o cristianismo não religioso, elaborado por Gianni Vattimo, com uma religião débil da caridade, centrada na caridade, que é o amor em movimento nas relações interhumanas, sociais e ecológicas. Para atingir esse objetivo, esse cristianismo foi conceituado conforme a decifração hermenêutica feita acerca de algumas obras do filósofo italiano e colocado em debate com Richard Rorty, René Girard e John Caputo, seus interlocutores em obras feitas em forma de diálogos e de exposições textuais.

O cristianismo não religioso de Vattimo é uma proposta que surgiu como forma de ultrapassar a religião institucional, especialmente a religião cristã católica, que segundo o autor apropriou-se de uma metafísica ontoteológica, fechando-se em seus dogmas, prescrições morais e normas disciplinares. Por isso, sua proposta possui concentração na caridade articulada com a kenosis do Verbo para apresentar o modus vivendi da fé cristã: operar a caridade, que é o amor radicado na vida humana. O debate com Rorty evidenciou que essa proposta indica uma religião cristã presente nas relações inter-humanas e, portanto, favorecendo a privatização da religião, ainda que tenha incidência social. No entanto, Girard chama atenção para o caráter institucional do cristianismo, no sentido de que instituir é fundar, fazendo-nos pensar na compreensão da arché ou a traditio que fundamenta o movimento cristão ao longo da história. Além disso, o debate com Caputo põe-nos a pensar sobre o efeito do pensamento débil aplicado ao cristianismo. Emerge um cristianismo de profundo caráter comunitário, que assume os loci historici dos fracos, constituindo-se como uma religião 
débil dos débeis da história, os interlocutores principais e preferidos do Deus revelado em Jesus Cristo, que doou o Espírito para que os seres humanos sejam livres.

A religião débil da caridade se situa no mundo pós-moderno, marcado pela multiplicidade cultural, pelo pluralismo religioso, pelos desafios de construção de uma política de cooperação entre os povos para a construção da justiça, da equidade econômica, da fraternidade nas relações diversas e pela efetividade do espírito da hospitalidade. Esse espírito denota a alteridade, tão necessária para que a religião se mostre débil, ao se efetivar na história como acolhimento a quem é diferente em cultura, religião, gênero e idade, de modo a configurar ideais em que a esperança se torna o movimento que busca realizar o que esse espera: a unidade dos povos, a pessoa compassiva e solidária e o amor realizado como caridade a partir dos débeis da terra.

\section{Referências}

CAPUTO, J. El poder de los débiles. In: ROBBINS, J. W. Después de la muerte de Dios. Conversaciones sobre religión, política y cultura. Barcelona; Buenos Aires; México: Paidós, 2010. p. 75-134; p. 169-232.

FORTES DE SALES, O. L. P. A vocação niilista da hermenêutica filosófica de Gianni Vattimo radicada no processo da secularização cristã. Horizonte, Belo Horizonte, v. 13, n. 39, p. 1580-1608, jul./set. 2015.

FRANCISCO, P. P. Exortação apostólica Evangelii Gaudium. São Paulo: Paulinas, 2013.

GADAMER, H. G. Verdade e Método (I). Traços fundamentais de uma hermenêutica filosófica. Petrópolis; Bragança Paulista: Vozes; São Francisco, 2003.

GEFFRÉ. C. De Babel a Pentecostes. Ensaios de teologia inter-religiosa. São Paulo: Paulus, 2013.

GIRARD, R. A violência e o sagrado. São Paulo: Paz e Terra/UNESP, 1990.

GIRARD, R. Não só interpretações, há também os fatos. In: ANTONELLO, P. (org.). Cristianismo e relativismo. Verdade ou fé frágil? Aparecida: Santuário, 2010. p. 95-119.

GIRARD, R. O Bode Expiatório. São Paulo: Paulus, 2004. 
GONÇALVES, P. S. L. Qual é locus de Deus: no túmulo ou no homem? A religião à luz da ontologia ou fenomenologia hermenêutica heideggeriana. Revista Numen, Juiz de Fora, v. 17, n. 2, p. 223-250, 2014.

GONÇALVES, P. S. L. Religião e espaço público: da luta à convivência. In: ROSSI, L. A.; JUNQUEIRA, S. (orgs.). Religião, Direitos Humanos \& Laicidade. São Paulo: Fonte Editorial, 2015. p. 111-122.

GONÇALVES, P. S. L. Religião e ética no cristianismo não religioso: uma abordagem a partir de Gianni Vattimo. Revista Pistis Prax. Teol. Past., Curitiba, v. 10, n. 2, p. 244268, maio/ago. 2018.

GONÇALVES, P. S. L.; SOUZA, N. Catolicismo e sociedade contemporânea. Do Concílio Vaticano I ao contexto histórico-teológico do Concílio Vaticano II. São Paulo: Paulus, 2013.

HABERMAS, J. Era das transições. Rio de Janeiro: Tempo Brasileiro, 2003.

HEIDEGGER, M. Phömenologie des religiösen Lebens. Frankfurt am Main: Vittorio Klostermann, 1995.

HEIDEGGER, M. Wegmarken. Gesamtausgabe 9. Frankfurt am Main: Vittorio Klostermann, 1976.

JOÃO PAULO II, P. P. Carta encíclica Evangelium Vitae. São Paulo: Paulinas, 1995.

LYOTARD, F. La condition postmoderne. Paris: Les Éditions de Minuit, 1979.

METZ, J. B. Memoria Passionis. Una evocación provocadora en una sociedad pluralista. Santander: Sal terrae, 2007.

MORRA, G. Il quarto uomo. Postmodernità o crisi della modernità? Roma: Armando Editore, 1992.

PAIVA, M. Da veritas a caritas: a religião depois da religião. Horizonte, Belo Horizonte, v. 13, n. 37, p. 406-427, jan./mar. 2015.

RORTY, R. Anticlericalismo e ateísmo. In: ZABALA, S. (org.). Il futuro dela religione. Solidarietà, carità, ironia. Milano: Garzanti, 2005. p. 33-46.

ROTTERDAN, S.; SENRA, F. O cristianismo não religioso de Gianni Vattimo: considerações para o senso religioso contemporâneo. Religare, João Pessoa, p. 96127, v. 12, n. 1, jun. 2015.

ROVATTI, P.; VATTIMO, G. Il pensiero debole. Milano: Feltrinelli, 1983.

TERRIN, A. N. Antropologia e horizontes do sagrado. Cultura e religiões. São Paulo: Paulus, 2004.

VATTIMO, G. A sociedade transparente. Lisboa: Relógio D’Água, 1992. 
VATTIMO, G. Girard e Heidegger: Kénosis e fim da metafísica. In: ANTONELLO, P. (org.). Cristianismo e relativismo. Verdade ou fé frágil? Aparecida: Santuário, 2010. p. 83-93.

VATTIMO, G. O vestígio do vestígio. In: DERRIDA, J.; VATTIMO, G. A Religião. São Paulo: Estação da Liberdade, 1994. p. 91-108.

VATTIMO, G.; GIRARD, R. Cristianismo e modernidade. In: ANTONELLO, P. (org.). Cristianismo e relativismo. Verdade ou fé frágil? Aparecida: Santuário, 2010. p. 23-48.

VATTIMO, G.; PATERLINI, P. Non essere Dio. Un'autobiografia a quattro mani. Reggio Emilia: Aliberti Editore, 2006.

VATTIMO, G. Adeus à verdade. Petrópolis: Vozes, 2016.

VATTIMO, G. Credere di credere. È possibile essere cristiani nonostante la Chiesa? Milano: Garzanti Elefanti, 1998.

VATTIMO, G. Essere e dintorni. Milano: La nave di Teseo editore, 2017.

VATTIMO, G. O fim da modernidade. Niilismo e hermenêutica na cultura pósmoderna. São Paulo: Martins fontes, 2002.

ZABALA, S. (org.). Il futuro dela religione. Milano: Garzanti, 2005. 